\title{
Hydraulic failure and repair are not routine in trees
}

\section{Hervé Cochard \& Sylvain Delzon}

\section{Annals of Forest Science}

Official journal of the Institut National de la Recherche Agronomique (INRA)

ISSN 1286-4560

Volume 70

Number 7

Annals of Forest Science (2013) 70:659-661

DOI 10.1007/s13595-013-0317-5

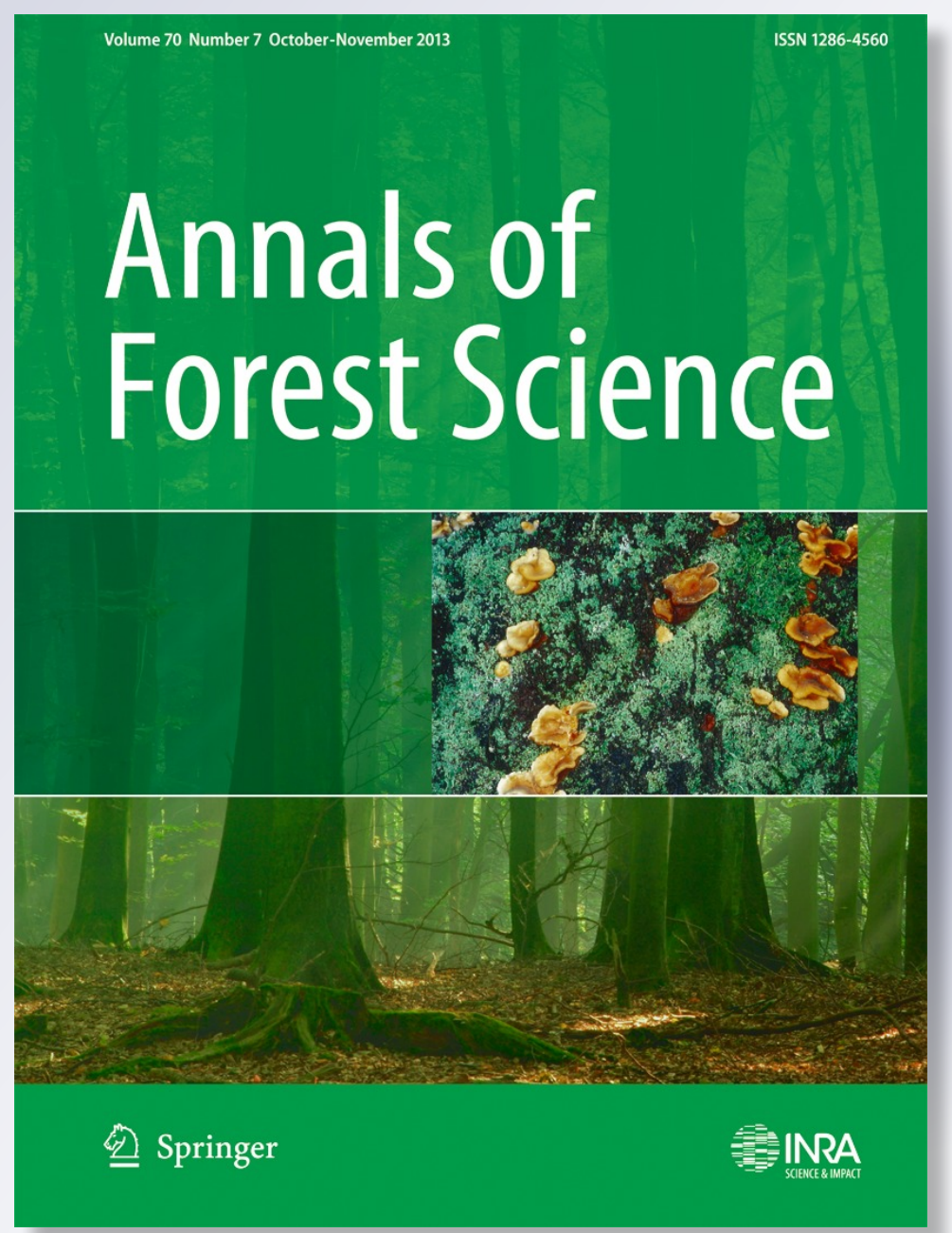

留 Springer 
Your article is protected by copyright and all rights are held exclusively by INRA and Springer-Verlag France. This e-offprint is for personal use only and shall not be selfarchived in electronic repositories. If you wish to self-archive your article, please use the accepted manuscript version for posting on your own website. You may further deposit the accepted manuscript version in any repository, provided it is only made publicly available 12 months after official publication or later and provided acknowledgement is given to the original source of publication and a link is inserted to the published article on Springer's website. The link must be accompanied by the following text: "The final publication is available at link.springer.com". 


\title{
Hydraulic failure and repair are not routine in trees
}

\author{
Hervé Cochard • Sylvain Delzon
}

Received: 8 July 2013 / Accepted: 12 July 2013 /Published online: 2 August 2013

(C) INRA and Springer-Verlag France 2013

Keywords Cavitation $\cdot$ Embolism $\cdot$ Water relations $\cdot$ Drought

Trees can pull tons of water up to $100 \mathrm{~m}$ above ground, whereas even the best engineered suction pumps can manage only $10 \mathrm{~m}$ at most. Beyond this height, the pull of gravity exceeds atmospheric pressure. The pressure at the top of the water column then becomes negative, and pumps drain by a process of vaporization called cavitation. So how do plants, particularly tall trees, cope with cavitation? Do they have an astonishingly high resistance to this process or are they routinely exposed to cavitation events and possess remarkable repair capacities? These questions were first asked when the mechanism of sap ascent in trees was discovered in the late nineteenth century (Brown 2013), but were not answered until reliable methods for measuring cavitation were introduced a century later. Early studies of plant hydraulics suggested that cavitation occurred only in conditions of severe drought (Fig. 1a). However, many studies carried out in the last decade have called this understanding of tree physiology and ecology into question. Diurnal cycles of cavitation and repair have been reported, even in well watered plants, suggesting that plants routinely face cavitation and recover easily from it. Writing in Plant Cell and Environment, Wheeler et al. (2013) provided compelling new experimental evidence that trees are much more resistant to cavitation than previously thought, demonstrating that this change of paradigm should now be reconsidered.

\section{Handling Editor: Erwin Dreyer}

H. Cochard $(\bowtie)$

INRA, UMR547 PIAF, Blaise Pascal University,

63100 Clermont-Ferrand, France

e-mail: herve.cochard@clermont.inra.fr

\section{S. Delzon}

INRA, UMR BIOGECO, University of Bordeaux,

33450 Talence, France

e-mail: sylvain.delzon@u-bordeaux1.fr
In plants, sap is transported under large negative pressures, in a network of tiny pipes forming the xylem tissue (Tyree 2003). The vulnerability of these pipes to cavitation can be assessed by plotting a "vulnerability curve" (Fig. 1b). The first of such curves were obtained in the 1980s by dehydrating branches and measuring the impact of cavitation on xylem hydraulic conductance (Sperry et al. 1988). The method was laborious, but the resulting "sigmoidal" curves were found to be highly consistent with what was known about tree water relations. Indeed, the plumbing system of trees appeared to be remarkably resistant to cavitation events. Cavitation occurred only when the xylem pressure fell below a threshold value more negative than that occurring in the absence of stress (Choat et al. 2012). Under this high-cavitation-resistance paradigm, cavitation was seen as an exceptional process occurring only after prolonged water stress with the drought tolerance of the tree depending on its capacity to avoid cavitation (Brodribb and Cochard 2009; Brodribb et al. 2010; Urli et al. 2013). For the first time, a mechanistic explanation for stomatal closure and tree death during water stress had been identified, and this was considered a major advance in the understanding of tree water relations.

In the late 1990s, a new paradigm was proposed to account for the functioning of many tree species with xylem pipes that appeared to be highly vulnerable (Tyree et al. 1999). The vulnerability curves of these species are typically "exponential" (Fig. 1b), suggesting that cavitation occurs as soon as xylem pressure falls below zero (for instance $50 \%$ of cavitation was reported at $-0.16 \mathrm{MPa}$ for Vitis vinifera $\mathrm{cv}$. Glenora by Jacobsen and Pratt (2012)). These trees are thus routinely exposed to high levels of cavitation even when well watered (Zwieniecki and Holbrook 1998). As a corollary, cavitation was found to be rapidly repaired by a mechanism that remains a matter of debate (Holbrook and Zwieniecki 1999). Under this low-cavitation-resistance paradigm, cavitation is seen as a process with beneficial effects on tree growth, possibly due to the release of water into the sap stream to sustain stomatal opening during the day. Drought tolerance may, therefore, be linked more to the ability of trees to repair cavitation than to 
a

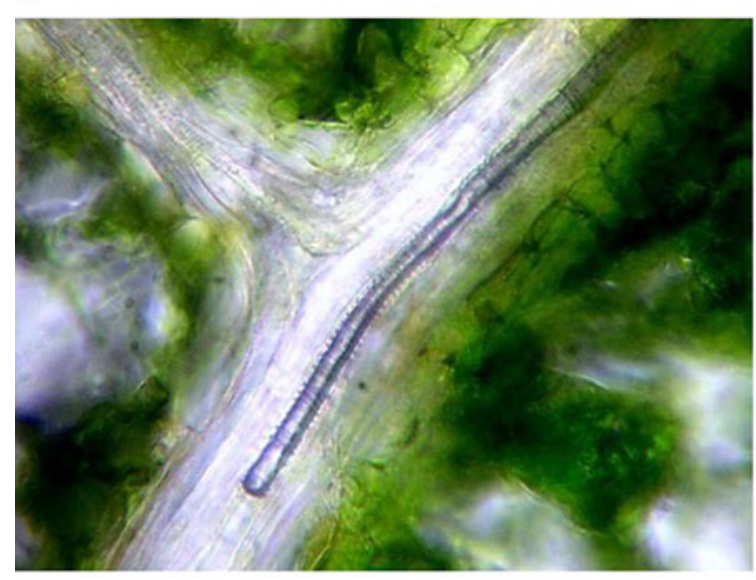

Fig. 1 Cavitation in plants. a Light micrograph showing an air bubble formed by cavitation in the vein of a walnut leaf. b Vulnerability curves showing the increase in cavitation with decreasing xylem pressure during drought. Cavitation was initially thought to occur only in conditions of intense drought stress after stomatal closure (plain blue curve). Studies

their capacity to avoid cavitation in the first place. Clearly, our perception of cavitation resistance in trees has changed dramatically in the last decade. A phenomenon that was once thought to occur only in extreme conditions is now considered very common. This has led to major efforts to unravel the mysterious mechanism by which trees repair their vulnerable pipes so efficiently.

However, through a new series of experiments, Wheeler et al. (2013) have shifted the burden of proof. They have identified methodological issues resulting in underestimations of the level of stress required to induce substantial cavitation in trees. The daily patterns of cavitation and apparent recovery in well-watered trees thus actually reflect a bias of the sampling procedure, which involves cutting stressed branches under water. If an appropriate sampling procedure (in which xylem tension is relaxed before sample excision) is used, cavitation levels remain low throughout the day. These findings indicate that diurnal cavitation and refilling cycles are artifactual in nature (Sperry 2013). This major finding is complementary to other recent reports (Cochard et al. 2010, 2013; McElrone et al. 2012) demonstrating that "exponential" curves are associated with the use of modern techniques that considerably overestimate xylem vulnerability to cavitation, particularly in species with long xylem pipes. These techniques were introduced in the 1990s and are now widely used in laboratories worldwide. The methodological contamination is actually massive as nearly half of all the hundreds of vulnerability curves published in the recent years are suspicious (Fig. 2).

The findings of Wheeler and his coworkers clearly invalidate the experimental proofs supporting "miraculous" refilling. Moreover, we now need to reconsider recent reports

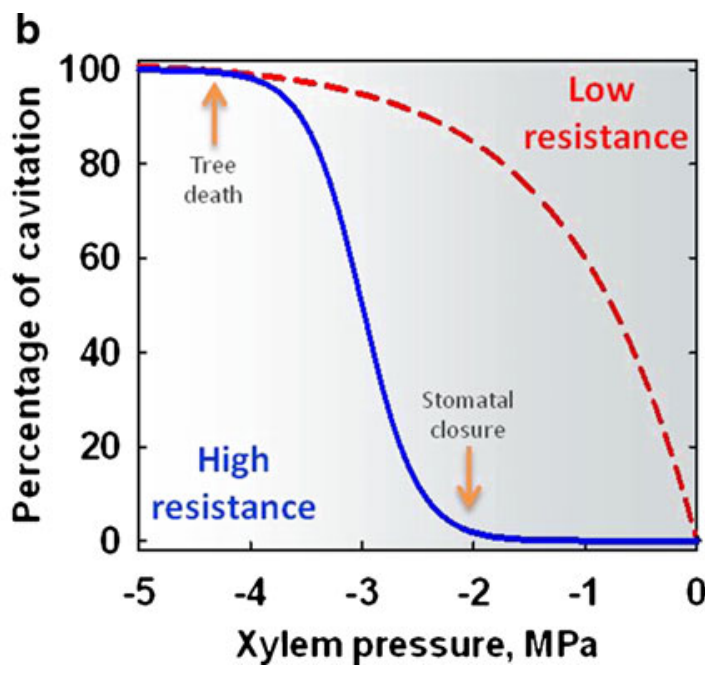

carried out in the last decade suggested that cavitation might be much more common than previously thought (dashed red curve). However, this view should now be overturned as major biases have been reported with the techniques used in recent years. Photo credits: Hervé Cochard (INRA, Clermont-Ferrand, France)

of incredibly high pipe vulnerability to cavitation if we are to understand tree drought resistance. Contrary to the prevailing view, hydraulic failure and repair are not routine in trees because, as in suction pumps, cavitation represents too serious a threat to the mechanism of sap ascent. Trees have a remarkable ability to construct a plumbing system that is outstandingly resistant to cavitation events until it is exposed to severe drought conditions. The high-cavitation-resistance paradigm must now be regarded as the only valid framework for

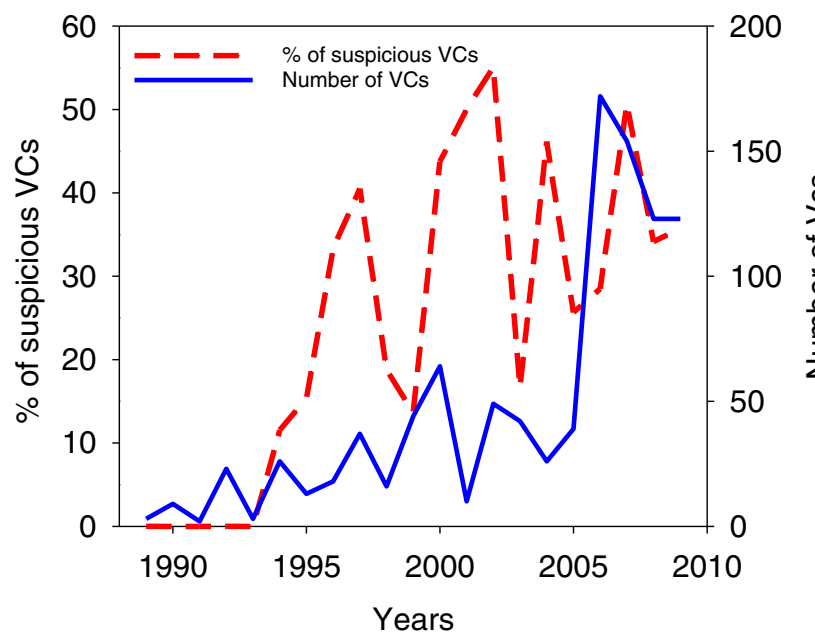

Fig. 2 The number of xylem vulnerability curves (VCs) published each year increases exponentially thanks to fast methods developed during the last two decades (plain blue curve). However, these techniques can be vitiated by an open-vessel artifact and the number of suspicious curves (i.e., having an exponential shape) is now reaching a critical level (dashed red curve). Data from Choat et al. (2012) 
understanding plant physiology and ecology. This will undoubtedly have profound implications for two of the major challenges posed by climate change: (1) identification of the molecular and genetic basis of drought resistance for the improvement of crop species, a key issue for the prevention of declining productivity in a context of global warming (Ciais et al. 2005); (2) improving the forecasting of global droughtinduced forest dieback (Allen et al. 2010; Lindenmayer et al. 2012) and species distribution shifts under climate change (Thuiller et al. 2005), by improving the representation of drought resistance in dynamic global vegetation models. We therefore urge plant and tree physiologists to reconsider existing datasets and to consolidate their methods for measuring cavitation resistance, to characterize lethal doses of water stress in plants.

\section{References}

Allen CD, Macalady AK, Chenchouni H, Bachelet D, McDowell N, Vennetier M, Kitzberger T, Rigling A, Breshears DD, Hogg EH, Gonzalez P, Fensham R, Zhang Z, Castro J, Demidova N, Lim J-H, Allard G, Running SW, Semerci A, Cobb N (2010) A global overview of drought and heat-induced tree mortality reveals emerging climate change risks for forests. For Ecol Manag 259:660-684

Brodribb TJ, Cochard H (2009) Hydraulic failure defines the recovery and point of death in water stressed conifers. Plant Physiol 149:575584

Brodribb TJ, Bowman D, Nichols S, Delzon S, Burlett R (2010) Xylem function and growth rate interact to determine recovery rates after exposure to extreme water deficit. New Phytol 188:533-542

Brown HR (2013) The theory of the rise of sap in trees: some historical and conceptual remarks. Phys Perspect. doi:10.1007/s00016-0130117-1

Choat B, Jansen S, Brodribb TJ, Cochard H, Delzon S, Bhaskar R, Bucci SJ, Feild TS, Gleason SM, Hacke UG, Jacobsen AL, Lens F, Maherali H, Martinez-Vilalta JM, Mayr S, Mencuccini M, Mitchell PJ, Nardini A, Pittermann J, Pratt RB, Sperry JS, Westoby M, Wright IJ, Zanne AE (2012) Global convergence in the vulnerability of forests to drought. Nature 491:752-755

Ciais P, Reichstein M, Viovy N, Granier A, Ogree J, Allard V, Aubinet M, Buchmann N, Bernhofer C, Carrara A, Chevallier F, de NobletDucoudré N, Friend AD, Friedlingstein P, Grünwald T, Heinesch B,
Keronen P, Knohl A, Krinner G, Loustau D, Manca G, Matteucci G, Miglietta F, Ourcival JM, Papale D, Pilegaard K, Rambal S, Seufert G, Soussana JF, Santz MJ, Schulze AD, Vesala T, Valentini R (2005) Europe-wide reduction in primary productivity caused by the heat and drought in 2003. Nature 437:529-533

Cochard H, Herbette S, Barigah T, Badel E, Ennajeh M, Vilagrosa A (2010) Does sample length influence the shape of xylem embolism vulnerability curves? A test with the Cavitron spinning technique. Plant Cell Environ 33:1543-1552

Cochard H, Badel E, Herbette S, Delzon S, Choat B, Jansen S (2013) Methods for measuring plant vulnerability to cavitation: a critical review. J Exp Bot. doi:10.1093/jxb/ert193

Holbrook NM, Zwieniecki MA (1999) Embolism repair and xylem tension: do we need a miracle? Plant Physiol 120:7-10

Jacobsen AL, Pratt RB (2012) No evidence for an open vessel effect in centrifuge-based vulnerability curves of a long-vesselled liana (Vitis vinifera). New Phytol 194:982-990

Lindenmayer DB, Laurance WF, Franklin JF (2012) Global decline in large old trees. Science 338:1305-1306

McElrone AJ, Brodersen CR, Alsina MM, Drayton WM, Matthews MA, Shackel KA, Wada H, Zufferey V, Choat B (2012) Centrifuge technique consistently overestimates vulnerability to water stressinduced cavitation in grapevines as confirmed with high-resolution computed tomography. New Phytol 196:661-665

Sperry JS (2013) Cutting-edge research or cutting-edge artifact? An overdue control experiment complicates the xylem refilling story. Plant Cell Environ. doi:10.1111/pce.12148

Sperry JS, Donnelly JR, Tyree MT (1988) A method for measuring hydraulic conductivity and embolism in xylem. Plant Cell Environ 11:35-45

Thuiller W, Lavorel S, Araujo MB, Sykes MT, Prentice IC (2005) Climate change threats to plant diversity in Europe. PNAS 102:8245-8250

Tyree MT (2003) The ascent of water. Nature 423:923

Tyree MT, Salleo S, Nardini A, Lo Gullo MA, Mosca R (1999) Refilling of embolized vessels in young stems of laurel. Do we need a new paradigm? Plant Physiol 120:11-21

Urli M, Porté A, Cochard H, Guengant Y, Burlett R, Delzon S (2013) Xylem embolism threshold for catastrophic hydraulic failure in angiosperm trees. Tree Physiol. doi:10.1093/treephys/tpt030

Wheeler JK, Huggett BA, Tofte AN, Rockwell FE, Holbrook NM (2013) Cutting xylem under tension or supersaturated with gas can generate PLC and the appearance of rapid recovery from embolism. Plant Cell Environ. doi:10.1111/pce.12139

Zwieniecki MA, Holbrook NM (1998) Diurnal variation in xylem hydraulic conductivity in white ash (Fraxinus americana L.), red maple (Acer rubrum L.) and red spruce (Picea rubens Sarg.). Plant Cell Environ 21:1173-1180 